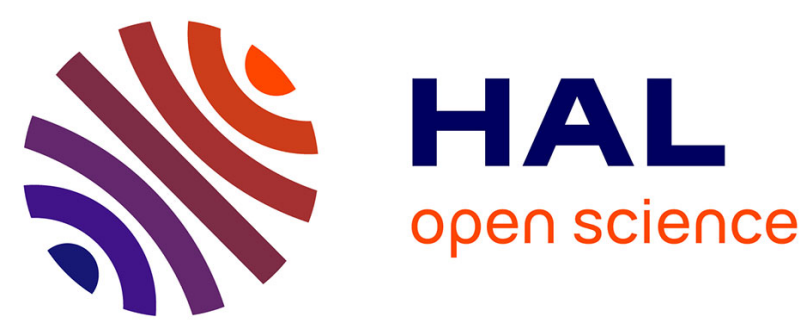

\title{
Dissolution and Passivation of a Silicon-Rich Austenitic Stainless Steel during Active-Passive Cycles in Sulfuric and Nitric Acid
}

Barbara Laurent, Nathalie Gruet, B. Gwinner, Frédéric Miserque, Karine Rousseau, Kevin Ogle

\section{To cite this version:}

Barbara Laurent, Nathalie Gruet, B. Gwinner, Frédéric Miserque, Karine Rousseau, et al.. Dissolution and Passivation of a Silicon-Rich Austenitic Stainless Steel during Active-Passive Cycles in Sulfuric and Nitric Acid. Journal of The Electrochemical Society, 2017, 164 (13), pp.C892-C900. $10.1149 / 2.1531713$ jes . cea-02429964

\section{HAL Id: cea-02429964 https://hal-cea.archives-ouvertes.fr/cea-02429964}

Submitted on 7 Jan 2020

HAL is a multi-disciplinary open access archive for the deposit and dissemination of scientific research documents, whether they are published or not. The documents may come from teaching and research institutions in France or abroad, or from public or private research centers.
L'archive ouverte pluridisciplinaire HAL, est destinée au dépôt et à la diffusion de documents scientifiques de niveau recherche, publiés ou non, émanant des établissements d'enseignement et de recherche français ou étrangers, des laboratoires publics ou privés. 


\title{
Dissolution and Passivation of a Silicon-Rich Austenitic Stainless Steel during Active-Passive Cycles in Sulfuric and Nitric Acid
}

\author{
Barbara Laurent, ${ }^{\mathrm{a}, \mathrm{b}, *}$ Nathalie Gruet, ${ }^{\mathrm{a}}$ Benoit Gwinner, ${ }^{\mathrm{a}}$ Frederic Miserque, ${ }^{\mathrm{a}}$ \\ Karine Rousseau, ${ }^{\mathrm{c}}$ and Kevin Ogle $\mathrm{e}^{\mathrm{b}, * *, \mathrm{z}}$ \\ ${ }^{a}$ Commissariat à l'Energie Atomique, Den-Service de la Corrosion et du Comportement des Matériaux dans leur \\ Environnement, Université Paris-Saclay, F-91191 Gif-sur-Yvette, France \\ ${ }^{b}$ Chimie-ParisTech, PSL Research University, IRCP-CNRS, 75005 Paris, France \\ ${ }^{c}$ Serma Technologies, BHT, Bâtiment 52, 38040 Grenoble, France
}

\begin{abstract}
The high Si containing X1CrNiSi18-15-4 stainless steel (SS) spontaneously forms a protective oxide film that is mostly composed of mixed chromium and silicon oxides. This film ensures a good durability of the industrial facilities the alloy was designed for, containing very acidic electrolytes such as hot and concentrated nitric acid, $\mathrm{HNO}_{3}$, in presence of oxidizing species. In the present work, the chemistry of the oxide formed and the passivation kinetics of the alloy in sulfuric acid, $\mathrm{H}_{2} \mathrm{SO}_{4}$, and for the first time in $\mathrm{HNO}_{3}$, were monitored by atomic emission spectroelectrochemistry (AESEC) over successive activation and passivation cycles of the material. X1CrNiSi18-15-4 SS was compared to a low Si containing SS, the X2CrNiN18-10 SS. It was found that a similar quantity and rate of passive film was formed during passivation, and dissolved during activation. Reproducible results were obtained over several active-passive cycles. The excess $\mathrm{Cr}$ was correlated with the dissolution rate decay during passivation. $\mathrm{The} \mathrm{Si} / \mathrm{Cr}$ ratio of the passive film was determined by X-ray photoelectron spectroscopy, energy dispersive X-ray spectroscopy (performed using transmission electron microscopy), and AESEC giving similar results within experimental error. The EDX profile suggest that the passive film consists of a Si rich outer and $\mathrm{Cr}$ rich inner layer.

(C) The Author(s) 2017. Published by ECS. This is an open access article distributed under the terms of the Creative Commons Attribution 4.0 License (CC BY, http://creativecommons.org/licenses/by/4.0/), which permits unrestricted reuse of the work in any medium, provided the original work is properly cited. [DOI: 10.1149/2.1531713jes] All rights reserved.

(cc) BY
\end{abstract}

Manuscript submitted August 10, 2017; revised manuscript received October 17, 2017. Published November 7, 2017.

The passivation of iron in nitric acid was first noted by Keir in $1790,{ }^{1}$ followed soon after by Berzelius and Hisinger ${ }^{2}$ and Schönbein ${ }^{3}$ between 1807 and 1836. In 1837, Faraday, in correspondence with Schönbein, ${ }^{4}$ made the first enunciation of the oxide-skin theory which has been extended to many materials ever since. Nowadays, corrosion prediction of stainless steels (SS) in acidic environment arises directly from the characterization of their passive layer, constitutive of the metal-electrolyte interface, ${ }^{5,6}$ whose chemistry and morphology determine the electrochemical behavior of the material in a given environment. This oxide layer of SS makes these alloys a very appropriate material choice for acidic environments. Nitric acid, $\mathrm{HNO}_{3}$, is used extensively for nuclear retreatment and the nuclear retreatment plants rely on the use of $18 \mathrm{Cr}-10 \mathrm{Ni}$ type SS such as the $304 \mathrm{~L}$ SS (X2CrNiN18-10). ${ }^{7}$ It has been demonstrated that a $3.5 \%$ Si composition improves the corrosion resistance of stainless steel in hot, concentrated nitric acid in the presence of oxidizing species although the origin of this improved performance has yet to be elucidated. ${ }^{37}$

It is generally acknowledged that the passive film has a bilayer structure with electron exchange occurring across the outer layer with the environment, and cation transfer across the inner layer. The dissolution rate of the material ${ }^{8,9}$ in the passive state is limited by cation transfer across the inner layer. The formation of the passive film depends on the electrochemical potential of the material/electrolyte combination. In the active domain, $\mathrm{Fe}$ and the alloying elements are expected to dissolve in proportions respecting the bulk material (congruent dissolution), following the oxidation reaction of the metal: ${ }^{8}$

$$
M \rightarrow M^{z+}+z e^{-}
$$

In the passive potential domain however, insoluble oxides of $\mathrm{Cr}$ (III) are formed. These oxides remain on the surface as a $\mathrm{Cr}$ (III) oxide film while the other elements dissolve via a process of selective dissolution. ${ }^{10-12}$ Thus a $\mathrm{Cr}$ enriched surface film results according to the following stoichiometry:

$$
\mathrm{Fe}_{\mathrm{x}} \mathrm{Cr}_{\mathrm{y}}+3 \mathrm{yH}_{2} \mathrm{O} \rightarrow \mathrm{xFe}^{2+}+\mathrm{y} \mathrm{Cr}(\mathrm{OH})_{3(\mathrm{~s})}+(2 \mathrm{x}+3 \mathrm{y}) \mathrm{e}^{-}+3 \mathrm{yH}^{+}
$$

\footnotetext{
*Electrochemical Society Student Member.

**Electrochemical Society Member.

${ }^{\mathrm{z}}$ E-mail: kevin.ogle@ chimie-paristech.fr
}

The potential domain where the oxides of $\mathrm{Cr}$ are protective is called the passive domain and is the most interesting for industrial applications. ${ }^{7}$ However, under certain conditions, this passivity can be broken at very low or at very high potentials, called respectively 'active' and 'transpassive' domains.

The transition from the passive to the active state may be characterized by the reduction of the passive film to yield soluble $\mathrm{Cr}^{2+} .{ }^{17}$

$$
\mathrm{Cr}(\mathrm{OH})_{3}(\mathrm{~s})+\mathrm{e}^{-} \rightarrow \mathrm{Cr}^{2+}+3 \mathrm{OH}^{-} \quad \mathrm{E}^{\circ}=-0.41 \mathrm{~V} \text { vs. } \mathrm{NHE}
$$

The transition from the passive to the transpassive state is usually associated with the oxidation of $\mathrm{Cr}(\mathrm{III})$ to $\mathrm{Cr}(\mathrm{VI})^{13}$ and $\mathrm{Cr}(\mathrm{VI})$ species are expected to be soluble in $\mathrm{HNO}_{3} .{ }^{17}$

$$
\begin{aligned}
& 2 \mathrm{Cr}(\mathrm{OH})_{3}(\mathrm{~s})+\mathrm{H}_{2} \mathrm{O} \rightarrow \mathrm{H}_{2} \mathrm{Cr}_{2} \mathrm{O}_{7}+6 \mathrm{H}^{+}+6 \mathrm{e}^{-} \\
& \mathrm{E}^{\circ}=+1.37 \mathrm{~V} \text { vs. NHE }
\end{aligned}
$$

A $4 \mathrm{~mol} \mathrm{dm}^{-3} \mathrm{HNO}_{3}$ solution at $100^{\circ} \mathrm{C}$ displays an equilibrium state potential on a platinum wire of $1.20 \mathrm{~V}$ vs. NHE ${ }^{14}$ which enables $18 \mathrm{Cr}-10 \mathrm{Ni}$ type $\mathrm{SS}$ to be passive. However, due to the industrial processes that can be performed in $\mathrm{HNO}_{3}$, oxidizing species may be present that increase the potential of the electrolyte, leading to the possibility of a passivity breakdown following Eq. 4.,15,16 A high silicon enrichment (over $1 \mathrm{wt} \%$ ) of a $18 \mathrm{Cr}-15 \mathrm{Ni}$ SS proved to lower the risk associated with such passivity breakdown in the presence of oxidizing species. ${ }^{18-24,37}$ The X1CrNiSi18-15-4 SS (composition given in Table I) was designed for these kinds of electrolytes, where its dissolution rate was shown to be lower than for the X2CrNiN18-10 SS. It is however not the case in pure $\mathrm{HNO}_{3}$, where the $\mathrm{X} 1 \mathrm{CrNiSi} 18-15-4$ SS dissolves more rapidly than the $\mathrm{X} 2 \mathrm{CrNiN} 18-10 \mathrm{SS}$, and this is probably due to the properties of the particular passive layer of the X1CrNiSi18-15-4 SS. This film is composed of a silicon rich oxide, very likely chromium silicate whose stoichiometry and thickness have not been clearly determined, ${ }^{36}$ nor observed in situ over the very first seconds of formation. A first attempt of characterization of this oxide layer was made in previous work, ${ }^{25}$ through the measurement of the activation potential, which should be directly related to $\mathrm{E}^{\circ}$ of Eq. 3 . For the X1CrNiSi18-15-4 SS, the activation potential was higher than $\mathrm{E}^{\circ}$ for Eq. 3, highlighting the thermodynamic differences between a pure chromium oxide and a mixed $\mathrm{Si}-\mathrm{Cr}$ oxide. 
Table I. Mass composition of X1CrNiSi18-15-4 and X2CrNiN1810 SS determined by GDOES profiles performed on samples and averaged between $40 \mu \mathrm{m}$ and $50 \mu \mathrm{m}$ depth expressed in wt $\%$.

$\mathrm{Fe} \quad \mathrm{Cr} \quad \mathrm{Ni} \quad \mathrm{Si} \quad \mathrm{Mn} \quad \mathrm{Cu}$ Mo Add.

$\begin{array}{lllllllll}\text { X1CrNiSi18-15-4 SS } & 59.76 & 18.79 & 15.08 & 3.54 & 1.97 & 0.18 & 0.05 & 0.68\end{array}$ $\begin{array}{lllllllll}\mathrm{X} 2 \mathrm{CrNiN} 18-10 \mathrm{SS} & 70.35 & 17.78 & 9.51 & 0.34 & 1.46 & 0.16 & 0.19 & 0.21\end{array}$

Among the numerous possibilities to investigate the passivation of metals in situ, for example via surface analysis, ${ }^{6,26,27}$ Ogle et al. ${ }^{28}$ proposed an innovative protocol by monitoring the elemental dissolution of SS during the cyclic formation and dissolution of passive films in sulfuric acid, $\mathrm{H}_{2} \mathrm{SO}_{4}$, for low-Si containing SS, (X2CrNiN18-10 SS). This method relied on the atomic emission spectroelectrochemistry (AESEC) technique where an electrochemical flow cell is coupled to an inductively coupled plasma atomic emission spectrometer (ICP-AES). When dissolving, metal ions of the sample are transported downstream to the ICP-AES where they can be analyzed in real time giving the rate of elemental dissolution directly, and giving precious information on the kinetics of passivation indirectly via mass balance. Ogle et al. ${ }^{28}$ proved that it was possible in $\mathrm{H}_{2} \mathrm{SO}_{4}$ for the $\mathrm{X} 2 \mathrm{CrNiN} 18-10 \mathrm{SS}$, to switch reversibly from active to passive domains using short polarization pulses. Both states were stable over a few hundred seconds. Simultaneously, they recorded and analyzed the dissolution of each major element of the SS as a function of time during the cycles. From a mass balance, the $\mathrm{Cr}$ enrichment of the passive layer was quantified during the cycles, representing a growth of the passive film during passivation and a loss of the passive film during activation.

The present work aims at determining if the high concentration of $\mathrm{Si}$ in the passive layer of the X1CrNiSi18-15-4 SS impacts the kinetics of passivation of the material and extends this earlier work to nitric acid. It must be noted that performing similar experiments in concentrated $\mathrm{HNO}_{3}$ comes with several difficulties. $\mathrm{HNO}_{3}$ is both an acid and a strong oxidizing agent, reducing through numerous cathodic processes at high potentials. ${ }^{14,29}$ Therefore, in concentrated $\mathrm{HNO}_{3}$, SS will usually undergo spontaneous passivation and it is rarely possible to observe a stable active dissolution of the material without adding chlorides for example. ${ }^{30}$ In the potential range of the active domain of SS, the overall current is strongly cathodic. Therefore, the observation of the active dissolution of $\mathrm{SS}$ in $\mathrm{HNO}_{3}$ must be performed under controlled polarization conditions of the sample (potentiostatic or galvanostatic mode), activation and passivation being the transient periods between open circuit potential and polarized activation.

The experimental strategy of the present work is to investigate the impact of silicon on the oxide layer of stainless steels, by comparing the X1CrNiSi18-15-4 SS and the X2CrNiN18-10 SS oxide layers in $\mathrm{H}_{2} \mathrm{SO}_{4}$, and establish some parallels with $\mathrm{HNO}_{3}$ using in situ and ex situ techniques. The $\mathrm{X} 2 \mathrm{CrNiN18-10} \mathrm{SS}$ alloy was chosen as a reference material for this work because its composition is similar to the materials used in the nuclear retreatment facilities containing hot and concentrated acids. The impact of $\mathrm{Ni}$ concentration in the composition of the steel on the formation and dissolution of the passive layer is usually considered to be insignificant, $\mathrm{Ni}$ serving to stabilize the austenitic phase without affecting the corrosion resistance. ${ }^{31}$ Based on these results, a structure for the oxide layer of the $\mathrm{X} 1 \mathrm{CrNiSi} 18-15-4$ $\mathrm{SS}$ is proposed and characterized by its $\mathrm{n}_{\mathrm{Cr}} / \mathrm{n}_{\mathrm{Si}}$ molar ratio.

\section{Experimental}

Materials and electrolytes.-X1CrNiSi18-15-4 SS and $\mathrm{X} 2 \mathrm{CrNiN} 18-10$ SS used in the present work were cut into $20 \mathrm{~mm} \times 20 \mathrm{~mm} \times 1 \mathrm{~mm}$ samples. The elemental analyses of the steels were performed by glow discharge optical emission spectroscopy (GDOES) using a GD-Profiler from Horiba Jobin-Yvon. From the signals given by the GDOES, the bulk of the sample was reached between 40 and $50 \mu \mathrm{m}$ depth and the composition of the steel was averaged over two craters on different samples. This analysis is given in Table I. X1CrNiSi18-15-4 and $\mathrm{X} 2 \mathrm{CrNiN} 18-10 \mathrm{SS}$ are very similar SS in composition, except for silicon and nickel. Prior to analysis, samples were cleaned with ethanol and acetone in an ultrasonic bath, then polished to $0.03 \mu \mathrm{m}$ diamond finish. Polishing ensured good sealing in the AESEC flow cell and allowed ex situ surface analysis of the sample as required.

Deionized water $(18.2 \mathrm{M} \Omega \mathrm{cm})$ was prepared with a Millipore system and used for all electrolytes. Sulfuric acid $96 \%$ and nitric acid $68 \%$ (Sigma Aldrich) were used to prepare the solutions. All glassware was protected with a paraffin film to avoid any hazardous contamination.

X-ray photoelectron spectroscopy (XPS)._XPS analyses were carried out with a Thermofisher Escalab 250 XI spectrometer using a monochromatic X-ray $\mathrm{Al} \mathrm{K} \alpha$ source. The instrument was calibrated in energy with the $\mathrm{Ag}$ Fermi level $(0 \mathrm{eV})$ and the $3 d_{5 / 2}$ core level of metallic silver $(368.3 \mathrm{eV})$. The $\mathrm{C}-1 s$ signal was used to correct a possible charge effect: the $\mathrm{CC} / \mathrm{CH}$ contribution of $\mathrm{C}-1 s$ spectra was fixed at $285.0 \mathrm{eV}$. The analysis zone consisted of a $900 \mu \mathrm{m}$ diameter spot. The data processing was performed using the commercially available Avantage software. For the fitting procedure, a Shirley background has been used and Lorentzian-Gaussian (L/G) ratio was fixed at $30 \%$. Main parameters used to decompose XPS spectra are presented in Table II.

Transmission electron microscopy (TEM) and X-ray energy dispersion spectroscopy $(X-E D S)$. - Cross-sections of materials passivated in $4 \mathrm{~mol} \mathrm{dm}^{-3} \mathrm{HNO}_{3}$ at $100^{\circ} \mathrm{C}$ were analyzed using transmission electron microscopy (TEM) in high resolution imaging mode. These studies were performed by Serma Technologies (France). In order to identify zones of interest on each sample, electron backscattered diffraction (EBSD) was performed at the surface of the materials prior to sample cross-section elaboration, using a scanning electron microscope field emission gun Gemini 500 (ZEISS) scanning electron microscope (SEM), a Hikari Super charge coupled device (CCD) camera, and OIM data collection and analysis software for the acquisition and treatment of the data. Cross-section TEM lamellas were thinned using focused ion beam (FIB) FEI Strata DB400 and analyzed with a FEI Tecnai Osiris TEM using a an accelerating voltage of $200 \mathrm{kV}$ and equipped with ChemiSTEM and GIF Quantum detectors X-ray energy dispersive spectroscopy (X-EDS).

Electrochemistry and flow cell.- The AESEC flow cell has been described in detail previously. ${ }^{32,33}$ The flow cell consisted of a small volume working electrode compartment (approximately $0.2 \mathrm{~cm}^{3}$ ) with electrolyte input at the bottom and output at the top. The flow rate was measured accurately (1\% precision) for each experiment and nominally $3 \mathrm{~cm}^{3} \mathrm{~min}^{-1}$. Counter and reference electrodes were in a larger compartment separated from the working electrode by a porous membrane to allow passage of electrical current but avoid bulk mixing

Table II. Parameters used for the deconvolution of XPS spectra (Avantage software) Binding energies and full width at half maximum (FWHM).

Fe oxide contributions

\begin{tabular}{|c|c|c|c|c|c|c|c|}
\hline & \multicolumn{2}{|c|}{ Fe oxide contributions } & \multicolumn{3}{|c|}{ Cr oxide contributions } & \multicolumn{2}{|c|}{ Si oxide contributions } \\
\hline & $\mathrm{Fe}-2 p_{3 / 2}$ & $\mathrm{Fe}-2 p_{3 / 2}$ & $\mathrm{Cr}-2 p_{3 / 2}$ & $\mathrm{Cr}-2 p_{3 / 2}$ & $\mathrm{Cr}-2 \mathrm{p}_{3 / 2}$ & $\mathrm{Si}-2 p_{3 / 2}$ & $\mathrm{Si}-2 p_{I / 2}$ \\
\hline Binding Energy/eV & $709.7 \pm 0.3$ & $712.1 \pm 0.3$ & $576.3 \pm 0.3$ & $577.3 \pm 0.3$ & $579.0 \pm 0.3$ & $102.1 \pm 0.3$ & $102.7 \pm 0.3$ \\
\hline FWHM/eV & 2.36 & 2.93 & 1.08 & 1.92 & 1.71 & 1.36 & 1.32 \\
\hline
\end{tabular}


Table III. Wavelengths used for each major element of the two stainless steels, corresponding atomic weights and detection limits associated (averaged over 10 experiments).

\begin{tabular}{|c|c|c|c|c|c|}
\hline & $\mathrm{Fe}$ & $\mathrm{Cr}$ & $\mathrm{Ni}$ & $\mathrm{Si}$ & $\mathrm{Mn}$ \\
\hline Wavelength/nm & 259.940 & 283.563 & 231.604 & 251.611 & 257.610 \\
\hline Detection limit in $\mathrm{H}_{2} \mathrm{SO}_{4} \mathrm{C}_{3 \sigma} / \mu \mathrm{g} \mathrm{dm}^{-3}$ & 2.3 & 0.12 & 4.4 & 3.6 & 1.9 \\
\hline Detection limit in $\mathrm{HNO}_{3} \mathrm{C}_{3 \sigma} / \mu \mathrm{g} \mathrm{dm}-3$ & 12.1 & 7.3 & 27.3 & 30 & 1.0 \\
\hline
\end{tabular}

of the two solutions. An analysis of the solution contained in the second compartment ensured a negligible quantity of metallic ions passed through the membrane. The working electrode was the stainless steel specimen, the counter electrode was a Pt grid, and the reference electrode was a $\mathrm{Hg} / \mathrm{Hg}_{2} \mathrm{SO}_{4}$ electrode (MSE, $\mathrm{E}=+0.65 \mathrm{~V}$ vs. NHE in saturated $\mathrm{K}_{2} \mathrm{SO}_{4}$ ). A Gamry Reference 600 potentiostat functioning in the potentiostatic mode was used to control the potential and measure the electrochemical current density, $\mathrm{j}_{\mathrm{e}}$. The analog outputs of the potentiostat were fed into the A/D converter and data acquisition software of the ICP-AES spectrometer so that the ICP-AES intensity data and the electrochemical data were on exactly the same time scale.

The AESEC experiments were performed at a temperature of $28^{\circ} \mathrm{C}$ ( $301 \mathrm{~K})$ using a recirculating water system connected to a thermocryostat (Lauda) constant temperature bath. Water from the bath was circulated through a hollow copper block connected to the rear of the working electrode (SS studied) so that the electrode was heated directly. Electrical isolation between the block and the sample was designed to prevent both current leakage and ensure heat transfer. Spontaneous passivation of samples for other surface analysis (several XPS and TEM-EDX measurements) was performed at $100^{\circ} \mathrm{C}(373 \mathrm{~K})$ in a $200 \mathrm{~mL}$ jacketed reactor using similar recirculating oil system connected to a thermocrystotat (Lauda).

Polarization curves were performed at a scan rate of $0.2 \mathrm{mV} \mathrm{s}^{-1}$ in the anodic direction using the flowcell for both $\mathrm{SS}$ in $\mathrm{H}_{2} \mathrm{SO}_{4}$ and $\mathrm{HNO}_{3}$ electrolytes of comparable protonic concentration $\left(\mathrm{C}_{\mathrm{H}}{ }^{+}=\right.$ $\left.2 \mathrm{~mol} \mathrm{dm}^{-3}\right)$.

Atomic emission spectroelectrochemistry.-The experimental set-up including data acquisition has also been described in detail previously. ${ }^{32}$ Briefly, the working electrode releases ions into the electrolyte in the flow cell which is then continuously fed into the plasma of the ICP-AES where the emission intensities of the different ions are measured simultaneously. These emission intensities are converted into concentration using standard ICP-AES calibration techniques. Electrolyte transport is done using a peristaltic pump and the input to the plasma uses a concentric glass nebulizer and a cyclonic spray chamber. The ICP-AES used in this work was an Ultima 2C from Horiba Jobin-Yvon consisting of a $40.68 \mathrm{MHz}$ inductively coupled Ar plasma, operating at $1 \mathrm{~kW}$ and interfaced to independent polychromator and monochromator optical modules. A $50 \mathrm{~cm}$ focal length Paschen-Runge polychromator was used equipped with an array of photomultiplier tube detectors at given wavelengths allowing the measurement of 30 preselected elements simultaneously. Emission wavelengths were chosen for maximum sensitivity and low interferences. The monochromator $(1 \mathrm{~m}$ focal length) with a Czerny-Turner configuration was dedicated for high spectral resolution of a single element. In the present work, the monochromator was used to monitor the $\mathrm{Cr}$ signal. Wavelengths used for each element and corresponding typical detection limits are given in Table III. Note that the detection limit was measured for each experiment and may vary depending on the conditions of the plasma.

AESEC data treatment.-For each element $\mathrm{M}$, the instantaneous dissolution rate $v_{M}$ was calculated from the instantaneous elemental concentration $\mathrm{C}_{\mathrm{M}}:^{32}$

$$
v_{M}=f \frac{C_{M}}{A}
$$

where $\mathrm{f}$ is the flow rate of the electrolyte and $\mathrm{A}$ is the surface area of the working electrode. The total dissolution rate $v_{\Sigma}$ can be defined as the sum of the dissolution rates of the measured elements:

$$
v_{\Sigma}=\sum v_{M}
$$

The detection limits $3 \sigma$ are calculated as following (Table III):

$$
C_{3 \sigma}=3 \frac{\sigma_{\text {blank }}}{\alpha}
$$

where $\sigma_{\text {blank }}$ is standard deviation of the background and $\alpha$ sensitivity factor calculated from the calibration curves of each element at their specific wavelength. To facilitate comparison with the electrochemical current density, $j_{e}$, it is sometimes convenient to present the dissolution rate data as an equivalent faradaic current, $\mathrm{j}_{\mathrm{M}}$,

$$
\mathrm{j}_{\mathrm{M}}=\mathrm{n}_{\mathrm{e}_{\mathrm{M}}} \mathrm{F} v_{M}
$$

where $n_{e_{M}}$ is the number of electrons transferred in the dissolution reaction of $\mathrm{M}$ and $\mathrm{F}$ is the Faraday constant. $\mathrm{j}_{\Sigma}$ designates the sum of elemental current densities equivalent to Eq. 6.

The AESEC technique reveals whether or not a dissolution reaction is congruent or incongruent by comparing the composition of the electrolyte with that of the bulk metal. To this end the dissolution rate of an element, M, may be normalized to the bulk composition of the alloy:

$$
v_{\mathrm{M}}^{\circ}=\left(\mathrm{X}_{\mathrm{Fe}} / \mathrm{X}_{\mathrm{M}}\right) v_{\mathrm{M}}
$$

where $X_{M}$ is the mass fraction of element $M$ as determined by GDOES bulk analysis. For perfectly congruent dissolution, $\nu^{\circ} \mathrm{M}=v_{\mathrm{Fe}}$ while $\nu^{\circ}{ }_{M}>\nu_{F e}$ implies an excess of $\mathrm{M}$ is dissolving and $\nu^{\circ}{ }_{M}<v_{\mathrm{Fe}}$ implies that $\mathrm{M}$ is building up on the surface.

In the case of incongruent dissolution, it is possible to calculate the quantity of excess $M$ remaining on the surface. The method of estimating $\mathrm{Q}_{\mathrm{M}}$ was developed in detail previously. ${ }^{28}$ The rate of excess $M$ building up on the surface may be defined as:

$$
v_{M}^{\prime}=\frac{X_{M}}{X_{F e}} v_{F e}-v_{M}
$$

In this work, the surface enrichment of the alloy component $\mathrm{M}$, $\mathrm{Q}_{\mathrm{M}}$, may be obtained by integration of $v_{M}^{\prime}$.

$$
Q_{M}(t)=\int_{0}^{t} v_{M}^{\prime}(t) d t
$$

over the time period, t. In this work, we will use Eq. 11 to estimate the enrichments of $\mathrm{Cr}$ and $\mathrm{Si}$ on the surface during passivation and their subsequent dissolution during reactivation. It will be shown that these elements, in their oxidized form, are the principal components of the passive film and thusly, the AESEC methodology provides a real time quantitative kinetic analysis of passive film growth and dissolution. Further the extent of passivation (Eq. 11) may be correlated directly with the elemental dissolution rates (Eqs. 5 and 6).

\section{Results and Discussion}

Comparison of polarization curves of $\mathrm{SS}_{\text {in }} \mathrm{H}_{2} \mathrm{SO}_{4}$ and $\mathrm{HNO}_{3}$.An overview of the activation and passivation of a stainless steel specimen may be obtained by consideration of the elemental AESEC polarization curve, shown for the two grades of SS in $4 \mathrm{~mol} \mathrm{dm}^{-3} \mathrm{HNO}_{3}$ at room temperature in Fig. 1. The elemental AESEC polarization curve presents the conventional polarization curve, $\mathrm{j}_{\mathrm{e}} \mathrm{vs}$. E, as well as the total elemental dissolution current density, $\mathrm{j}_{\Sigma}$ (that takes into 

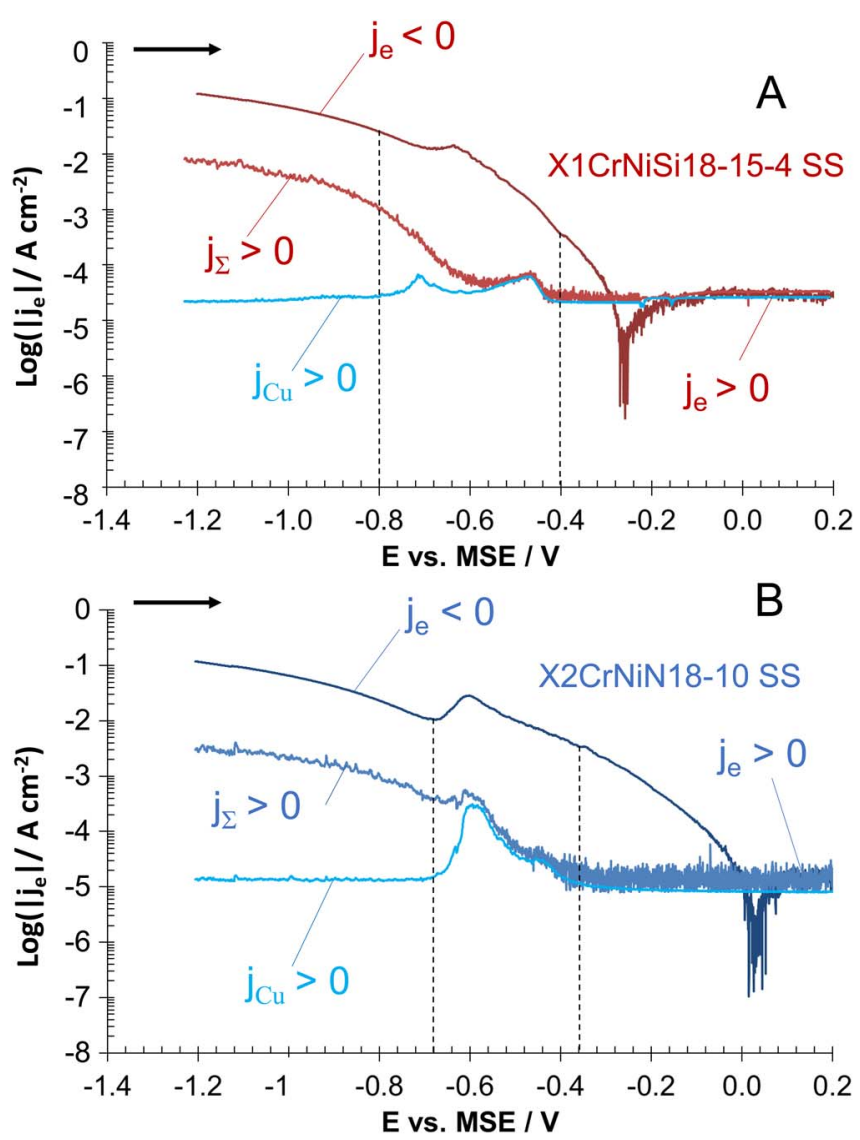

Figure 1. $\mathrm{j}_{\mathrm{e}}, \mathrm{j}_{\Sigma}$ and $\mathrm{j}_{\mathrm{Cu}}$ as a function of potential recorded during a linear sweep voltammetry performed on X1CrNiSi18-15-4 (A) and X2CrNiN18-10 $\mathrm{SS}(\mathrm{B})$ at $0.2 \mathrm{mV} \mathrm{s}^{-1}$ scan rate in $4 \mathrm{~mol} \mathrm{dm}^{-3} \mathrm{HNO}_{3} \mathrm{~T}=25^{\circ} \mathrm{C}$.

account elemental current densities of $\mathrm{Fe}, \mathrm{Cr}, \mathrm{Ni}, \mathrm{Si}, \mathrm{Mn}, \mathrm{Cu}$ ), and the dissolution current density of $\mathrm{Cu}, \mathrm{j}_{\mathrm{Cu}}$. The latter is represented separately in Fig. 1 as it is clear that all of the elements dissolved together except for $\mathrm{Cu}$. In $\mathrm{HNO}_{3}$, the cathodic reduction reaction can be distinguished as two main regions separated by a short peak of current for both SS around $-0.60 \pm 0.20 \mathrm{~V}$ vs. MSE. The electrical current density, $\mathrm{j}_{\mathrm{e}}$, of both steels superimpose accurately below $-0.80 \mathrm{~V}$ vs. MSE and differ above. A selective dissolution clearly occurs below $-0.80 \mathrm{~V}$ vs. MSE (dissolution of $\mathrm{Cu}$ is close to zero), then $\mathrm{Cu}$ dissolution occurs in two peaks between -0.80 and $-0.38 \mathrm{~V}$ vs. MSE as it is shown in Fig. 1. Cu dissolution was detected in $\mathrm{H}_{2} \mathrm{SO}_{4}$ around the same potentials by Ogle et al. ${ }^{35}$ and Ruel et al. ${ }^{36}$ but in the present work, the dissolution occurred systematically in two peaks whose origin is still unclear. However, as a result of this selective dissolution, a $\mathrm{Cu}$-rich layer can be expected to exist below $-0.80 \mathrm{~V}$ vs. MSE w then dissolves between -0.80 and $-0.38 \mathrm{~V}$ vs. MSE. It should be noted that this is quite consistent with thermodynamics as the transition $\mathrm{Cu}(0) \rightarrow \mathrm{Cu}(\mathrm{II})$ is expected around $-0.40 \mathrm{~V}$ vs. MSE. ${ }^{38}$ At this $\mathrm{Cu}$-rich surface, an enhancement of hydrogen reduction occurs ${ }^{29,30}$ and this explains why both SS display exactly the same current density in this region. Right after the $\mathrm{Cu}$-rich layer dissolution, given the potential domain, the reduction of nitric species is very likely to occur and the current density obtained is quite large. ${ }^{14}$

The results in Fig. 1 highlight the necessity of elemental rate data for the system $\mathrm{SS} / \mathrm{HNO}_{3}$ as the active to passive transition is not at all detectable in the $\mathrm{j}_{\mathrm{e}}$ vs. E curve but appears clearly as a decrease in the elemental dissolution rate over a potential range of approximately $-1 \mathrm{~V}$ to $-0.6 \mathrm{~V}$. In this same potential range, the electrical current density, $\mathrm{j}_{\mathrm{e}}$, is cathodic and on the order of several hundred $\mathrm{mA} \mathrm{cm}^{-2}$ while the anodic current associated with the passive to active transition, $\mathrm{j}_{\Sigma}$ is less than $1 \mathrm{~mA} \mathrm{~cm}^{-2}$ and was therefore completely masked. Also
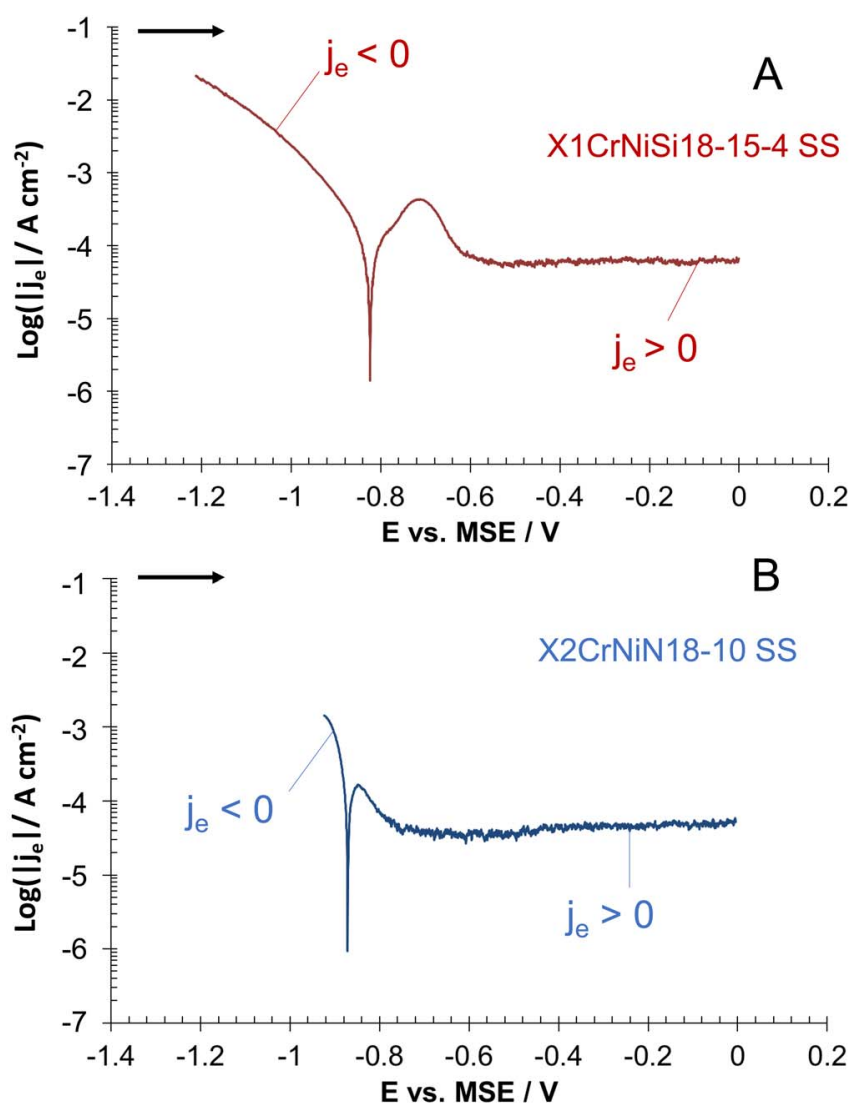

Figure 2. $\mathrm{j}_{\mathrm{e}}$ as a function of potential recorded during a linear sweep voltammetry performed on X1CrNiSi18-15-4 (A) and X2CrNiN18-10 SS (B) at $0.2 \mathrm{mV} \mathrm{s}^{-1}$ scan rate in $2 \mathrm{~mol} \mathrm{dm}^{-3} \mathrm{H}_{2} \mathrm{SO}_{4} \mathrm{~T}=25^{\circ} \mathrm{C}$.

resulting from this intense reduction reaction, the potentials corresponding to $j_{\mathrm{e}}=0$ are shifted anodically well into the passive domain. These values are very close to the open circuit potentials that were measured prior to the potential sweep. This result illustrates that SS in $\mathrm{HNO}_{3}$ spontaneously passivates and remains passive in $\mathrm{HNO}_{3}$.

Previous measurements of the activation potential for the passive to active transition gave a value of $-0.84 \pm 0.01 \mathrm{~V}$ vs. MSE in $4 \mathrm{~mol}$ $\mathrm{dm}^{-3} \mathrm{HNO}_{3}{ }^{25}$ for the X1CrNiSi18-15-4 SS. In contrast, the results of Fig. 1 indicate that the opposite transition, active to passive, is shifted in the cathodic direction for the formation of the passive film as compared to the dissolution of the passive film. The same tendency was pointed out by Lorbeer et al. ${ }^{34}$ on the active-passive and passiveactive transitions of $\mathrm{Fe}$ in $\mathrm{H}_{2} \mathrm{SO}_{4}$.

Identical experiments were conducted for SS in $2 \mathrm{~mol} \mathrm{dm}^{-3} \mathrm{H}_{2} \mathrm{SO}_{4}$ at room temperature, however as this system has been investigated in detail previously, ${ }^{28}$ only the conventional polarization curve $\left(\mathrm{j}_{\mathrm{e}} \mathrm{vs} . \mathrm{E}\right)$ are shown in Fig. 2. The active-passive transitions for both steels are clearly observed in $\mathrm{H}_{2} \mathrm{SO}_{4}$ occurring between -0.90 and $-0.50 \mathrm{~V}$ vs. MSE. However, the anodic maxima for the two cases is very close to the $\mathrm{j}_{\mathrm{e}}=0$ potential indicating that the cathodic current is quite large in this potential domain.

The effect of Si on the electrochemical behavior of SS may be determined by inspection of Figs. 1 and 2. First, the shape of the cathodic curves is very similar but the reduction reaction after $\mathrm{Cu}$ dissolution seems to be kinetically lowered for X1CrNiSi18-15-4 in both electrolytes. Second, in both electrolytes, the passive current of the X1CrNiSi18-15-4 SS is higher than for the X2CrNiN18-10 SS (respectively recorded $260 \pm 50$ and $125 \pm 50 \mathrm{nA} \mathrm{cm}^{-2}$ ). This is consistent with both electrochemical and gravimetric measurements performed in different parametrical studie ${ }^{39-42}$ showing that the X1CrNiSi 18-15$4 \mathrm{SS}$ in pure $\mathrm{HNO}_{3}$ dissolves more rapidly than the $\mathrm{X} 2 \mathrm{CrNiN} 18-10 \mathrm{SS}$. 


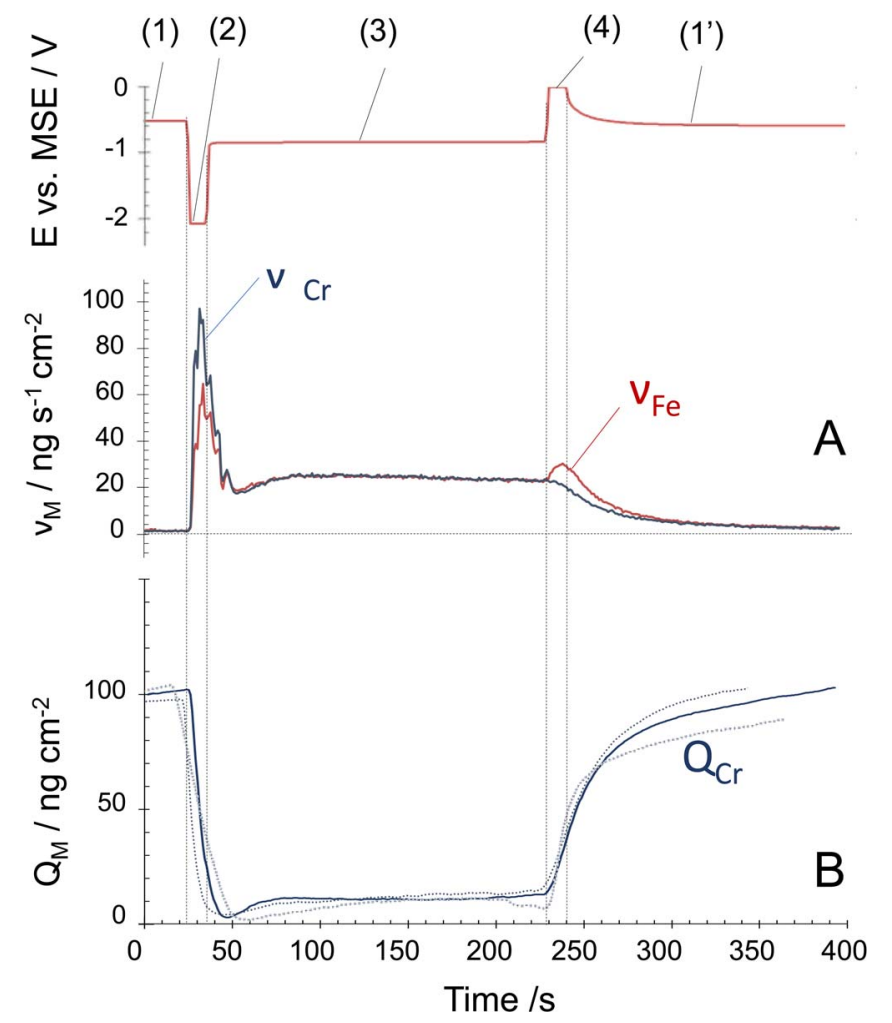

Figure 3. (A) Representative active - passive cycles for the X1CrNiSi18-15-4 $\mathrm{SS}$ in $2 \mathrm{~mol} \mathrm{dm}^{-3} \mathrm{H}_{2} \mathrm{SO}_{4} \mathrm{~T}=25^{\circ} \mathrm{C}$. A $/ \nu_{\mathrm{Fe}}$ and $\mathrm{v}^{\circ} \mathrm{Cr}$ vs. time. (B) $\mathrm{Q}_{\mathrm{Cr}}$ vs. time (3 cycles superimposed.).

This suggests that the oxide layer formed at the X1CrNiSi18-15-4 SS surface is less protective than for the $\mathrm{X} 2 \mathrm{CrNiN} 18-10$.

The kinetics of dissolution and passivation of $\mathrm{SS}$ in $\mathrm{H}_{2} \mathrm{SO}_{4}$ Passive film formation and dissolution was performed in $\mathrm{H}_{2} \mathrm{SO}_{4}$ during potentiostatic passivation and activation cycles, following the protocol of a previous publication. ${ }^{28}$ A single active-passive cycle for $\mathrm{X} 2 \mathrm{CrNiN} 18-10 \mathrm{SS}$ in $2 \mathrm{~mol} \mathrm{dm}^{-3} \mathrm{H}_{2} \mathrm{SO}_{4}$ is presented in Fig. $3 \mathrm{~A}$ and 4A. Shown are the dissolution rate of $\mathrm{Fe}, v_{\mathrm{Fe}}$, and the $\mathrm{Cr}$ and $\mathrm{Si}$ dissolution rates normalized to the Fe bulk composition, $\nu^{\circ}{ }_{M}$, via Eq. 9. A single activation-passivation cycle is divided into four time periods: (1) open circuit in passive domain; (2) activation, potentiostatic pulse at $-2.0 \mathrm{~V}$ vs. MSE for $10 \mathrm{~s}$; (3) open circuit in the active domain; (4) passivation, potentiostatic pulse at $0.0 \mathrm{~V}$ vs. MSE for $10 \mathrm{~s}$; (1') return to (1). The active and passive potentials for this work were chosen as $-2.0 \mathrm{~V}$ and $0.0 \mathrm{~V}$ respectively. For both steels and both electrolytes, $0 \mathrm{~V}$ vs. MSE appears in the passive domain and is sufficiently low to avoid any risk of transpassive dissolution (Fig. 2). A potential of $-2.0 \mathrm{~V}$ vs. MSE was chosen for the activation as it is well below the passive-active transition. The effect of potential and polarization time will be discussed later.

During period (1), the passivity of the alloy is evident as all $\nu^{\circ} \mathrm{M}$ are nearly zero and $\mathrm{E}_{\mathrm{oc}}=-0.50 \pm 0.05 \mathrm{~V}$ vs. MSE, consistent with the passive state (Fig. 2). In period (2), a sharp dissolution peak is observed, indicative of the enhanced dissolution following a cathodic activation. This is followed in period (3) by a steady increase in $v^{\circ} \mathrm{M}$ until a stable dissolution rate is obtained after approximately $200 \mathrm{~s}$. During this period, $\mathrm{E}_{\mathrm{OC}}=-0.82 \pm 0.05 \mathrm{~V}$ vs. MSE also consistent with the active state. Period (4) is characterized by a peak in the $\nu_{\mathrm{Fe}}$ whereas $\mathrm{Cr}$ and $\mathrm{Si}$ showed simply a steady decrease in intensity. This cycle was repeated four times and gave reproducible results.

Congruent dissolution during the active period 3 is clearly indicated as $\nu^{\circ}{ }_{M}=\nu_{\mathrm{Fe}}$ for both $\mathrm{M}=\mathrm{Cr}$ and $\mathrm{Si}$. This is consistent with the definition of the active domain as the oxide film formation rate

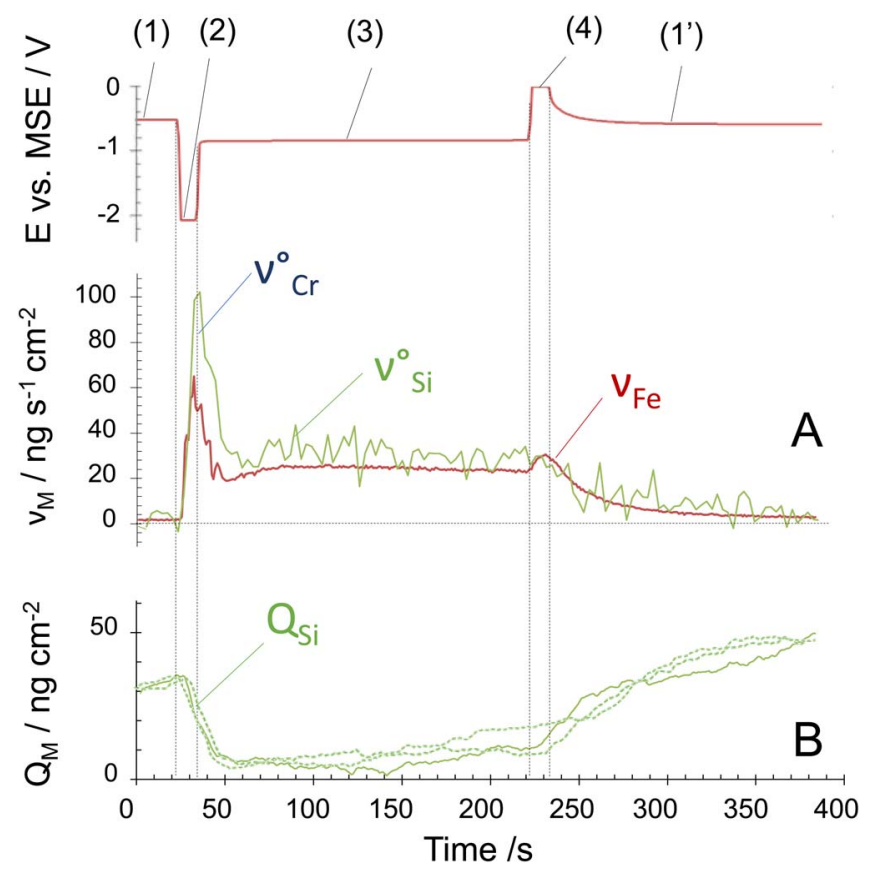

Figure 4. (A) Representative active - passive cycles for the $\mathrm{X} 1 \mathrm{CrNiSi} 18-15-4$ $\mathrm{SS}$ in $2 \mathrm{~mol} \mathrm{dm}{ }^{-3} \mathrm{H}_{2} \mathrm{SO}_{4} \mathrm{~T}=25^{\circ} \mathrm{C}$. A $/ \nu_{\mathrm{Fe}}$ and $\mathrm{v}^{\circ} \mathrm{Si}$ vs. time. (B) $\mathrm{QSi}_{\mathrm{Si}}$ vs. time (3 cycles superimposed.).

should be negligible as compared to the dissolution rate. ${ }^{43}$ It should be noted that using Fe as the reference element in Eq. 9 assumes that $\mathrm{Fe}$ is not contributing to the passive layer and that all oxidized $\mathrm{Fe}$ goes into solution. This hypothesis was confirmed by using $\mathrm{Mn}$ as the reference element (not shown), since soluble Mn(II) is expected to be the predominant $\mathrm{Mn}$ species across the entire range of applied potentials. ${ }^{17}$ In nitric acid, it was found that $\nu^{\circ}{ }_{\mathrm{Mn}} / \nu_{\mathrm{Fe}}=0.95 \pm 0.06$, demonstrating that $\mathrm{Fe}$ is a suitable reference element for this calculation, identical to the situation in $\mathrm{H}_{2} \mathrm{SO}_{4}{ }^{28} \mathrm{Fe}$ has been identified in the external layer of the passive film in various acidic electrolytes in several cases. ${ }^{49,50}$ However, the observation of Fe oxide in the passive film by XPS in $\mathrm{H}_{2} \mathrm{SO}_{4}$ and $\mathrm{HNO}_{3}$ remains tenuous. ${ }^{37,44}$ Yang et al. ${ }^{51}$ even found that $\mathrm{Fe}$ (II) was no longer detectable after 24 hours in the passive film formed in acidic electrolytes containing chlorides.

The important point to note in Fig. 3A and 4A is that a positive excess dissolution for both elements was recorded during activation of the surface. For the activation $\nu^{\circ} \mathrm{Cr}>v_{\mathrm{Fe}}$ and $\nu_{\mathrm{Si}}^{\circ}>v_{\mathrm{Fe}}$ suggesting an excess dissolution of $\mathrm{Cr}$ and $\mathrm{Si}$. This result is consistent with the dissolution of a pre-existing passive layer enriched in $\mathrm{Cr}$ and $\mathrm{Si}$. No significant selective dissolution of $\mathrm{Si}$ was detected for the X2CrNiN18-10 SS, consistent with the absence of Si in the oxide layer of this alloy. The opposite behavior is observed during passivation as $\mathrm{Cr}$. There is a significant peak in $\nu_{\mathrm{Fe}}$ while $\nu^{\circ} \mathrm{Cr}$ and $\nu^{\circ} \mathrm{Si}$ simply decrease. This is consistent with the preferential dissolution of Fe with $\mathrm{Cr}$ and $\mathrm{Si}$ remain on the surface contributing to the formation of the passive layer. Throughout the passivation cycle, $\nu^{\circ} \mathrm{Cr}<\nu_{\mathrm{Fe}}$ and $\nu_{\mathrm{Si}}^{\circ}<v_{\mathrm{Fe}}$ suggesting that $\mathrm{Cr}$ is building up on the surface again in the form of a $\mathrm{Cr}$ enriched passive film. This behavior was not observed for Ni nor for Mn.

The quantification of $\mathrm{Cr}$ and $\mathrm{Si}$ in the passive film may be achieved by mass balance (Eqs. 10 and 11). This is shown for X1CrNiSi1815-4 SS in Fig. 3B and Fig. 4B were the surface excesses of $\mathrm{Cr}$ and $\mathrm{Si}, \mathrm{Q}_{\mathrm{Cr}}$ and $\mathrm{Q}_{\mathrm{Si}}$, (Eq. 11) are given as a function of time. The results of three consecutive cycles are superimposed. From the graph, $\mathrm{Q}_{\mathrm{Cr}}$ cycles between 0 and $100 \mathrm{ng} \mathrm{cm}{ }^{-3}$ while $\mathrm{Q}_{\mathrm{Si}}$ cycles between 0 and $50 \mathrm{ng} \mathrm{cm}^{-3}$. For the activation period (2) $(\mathrm{t}=30$ to $60 \mathrm{~s})$ there is a clear decrease in $\mathrm{Q}_{\mathrm{Cr}}$ and $\mathrm{Q}_{\mathrm{Si}}$ associated with the dissolution of the passive film. There is no indication of film formation in the active period (3) and $\mathrm{Cr}$ and $\mathrm{Si}$ dissolution are congruent with $\mathrm{Fe}$. However, film 
formation occurs in the passivation period (4) and continues slowly during the open circuit passive period (1'). Note that the growth of the passive film expressed in excess $\mathrm{Cr}$ observed in periods (4) and (1') are within a few percent of the dissolution of the passive film in period (2).

The maximum quantity of excess $\mathrm{Cr}$ and $\mathrm{Si}\left(\Delta \mathrm{Q}_{\mathrm{Cr}_{\max }}\right.$ and $\left.\Delta \mathrm{Q}_{\mathrm{Simax}}\right)$ did not vary within experimental reproducibility $( \pm 10 \%)$ with the potentials and times of either activation or passivation as shown by the results of Table IV. Also shown in Table IV is the faradaic yield for passivation calculated as the ratio of the integrated external current, $\Delta \mathrm{n}_{e_{\text {ext }}}$, and the hypothetical current determined from elemental dissolution, $\Delta \mathrm{n}_{\mathrm{e}_{\text {ICP }}}$ :

$$
\begin{gathered}
\Delta \mathrm{n}_{\mathrm{e}_{e x t}}=\frac{1}{F} \int_{t 1}^{t 2} \mathrm{j}_{\mathrm{e}} \mathrm{dt} \\
\Delta \mathrm{n}_{\mathrm{e}_{\mathrm{ICP}}}=\int_{\mathrm{t} 1}^{t 2}\left(\frac{2 v_{\mathrm{Fe}}}{M_{F e}}+\frac{3 v_{\mathrm{Cr}}}{M_{C r}}+\frac{2 v_{\mathrm{Ni}}}{M_{N i}}+\frac{4 v_{\mathrm{Si}}}{M_{S i}}\right) \mathrm{dt}+4 \frac{Q_{S i}}{M_{S i}} \\
+3 \frac{Q_{C r}}{M_{C r}}
\end{gathered}
$$

where $t_{1}$ and $t_{2}$ refer to the beginning and end of the passivation period (4) with a total time of 100 seconds, and $M_{M}$ the molar mass of $M$. The comparison leads to very coherent results as the average ratio of the ionic dissolution to electrochemical current, $\Delta \mathrm{n}_{\mathrm{e}_{\mathrm{ICP}}} / \Delta \mathrm{n}_{\mathrm{e}_{\mathrm{ext}}}=0.9$ \pm 0.1 . This means that the entire current recorded by the potentiostat can be assigned to the dissolution of the material and the formation of the passive film within a $10 \%$ error. This result also highlights the high reliability of the quantitative measurement of the AESEC. Note that the $v_{\mathrm{M}}$ values in Eq. 13 were corrected for the descending background of the concentration due to the residence time distribution as described previously. ${ }^{28}$

The quantity of $\mathrm{Cr}$ determined in this work is curiously small as compared to what would usually be expected for a passive film. A very rough estimate of the thickness may be made from the approximately $100 \mathrm{ng} \mathrm{cm}^{-2} \mathrm{Cr}$ using the density of bulk $\mathrm{Cr}_{2} \mathrm{O}_{3}\left(5.21 \mathrm{~g} \mathrm{~cm}^{-3}\right)$ and assuming a uniform distribution on the surface. This leads to a hypothetical thickness of only $0.2 \mathrm{~nm}$, consistent with previous work. ${ }^{28}$ This is very small as compared to values reported in the literature ${ }^{52,53}$ and in fact is far from the $3 \mathrm{~nm}$ observed on the TE micrographs to be discussed later. For the most part however ex situ analysis has been done for films that were prepared after significantly longer passivation times and under more severe conditions. One possible explanation of the anomalously small value of the passive layer thickness is that the formation of the passive film occurs in two steps: (1) the very rapid formation of a "prepassive film", 53,54 followed by (2) a much slower growth of the film. Vetter ${ }^{12}$ showed that for passive iron a steady-state thickness of the passive film was reached asymptotically with time. In order to be detected by the ICP-AES, the dissolution/film formation reactions have to rise above the detection limit of the spectrometer and it is conceivable that only the very first instants of film formation yield such a high rate. Once the proto film is formed, the rate of dissolution would slow considerably. In fact, this is observed in Fig. 3 where the passive film continues to grow even after the applied potential has been stopped.

These results allow us to correlate the dissolution (corrosion) rate of the steel with the quantity of excess $\mathrm{Cr}$ in the passive film. During active dissolution $\left(\mathrm{Q}_{\mathrm{Cr}}=0\right)$, the open circuit potentials $(\mathrm{OCP})$ of both materials are very close $(-0.84 \pm 0.05 \mathrm{~V}$ vs. MSE for the $\mathrm{X} 2 \mathrm{CrNiN} 18-10 \mathrm{SS}$ and $-0.82 \pm 0.05 \mathrm{~V}$ vs. MSE for the X1CrNiSi1815-4 SS). However, $v_{\Sigma}$ differs by $30 \%$ between the two alloys $\left(60 \mathrm{ng} \mathrm{s}^{-1} \mathrm{~cm}^{-2}\right.$ for the X2CrNiN18-10 SS and $40 \mathrm{ng} \mathrm{s}^{-1} \mathrm{~cm}^{-2}$ for the X1CrNiSi18-15-4 SS). This means that the spontaneous corrosion rate of the $\mathrm{X} 2 \mathrm{CrNiN18}-10 \mathrm{SS}$ is more severe than that of X1CrNiSi18-15-4 SS at the same potential in $\mathrm{H}_{2} \mathrm{SO}_{4}$. This was not obvious based on Fig. 2 as the $\mathrm{j}_{\mathrm{e}}=0$ potential for X1CrNiSi18-15-4 SS active-passive transition is shifted by about $+200 \mathrm{mV}$ (anodic) as compared to $\mathrm{X} 2 \mathrm{CrNiN} 18-10 \mathrm{SS}$.

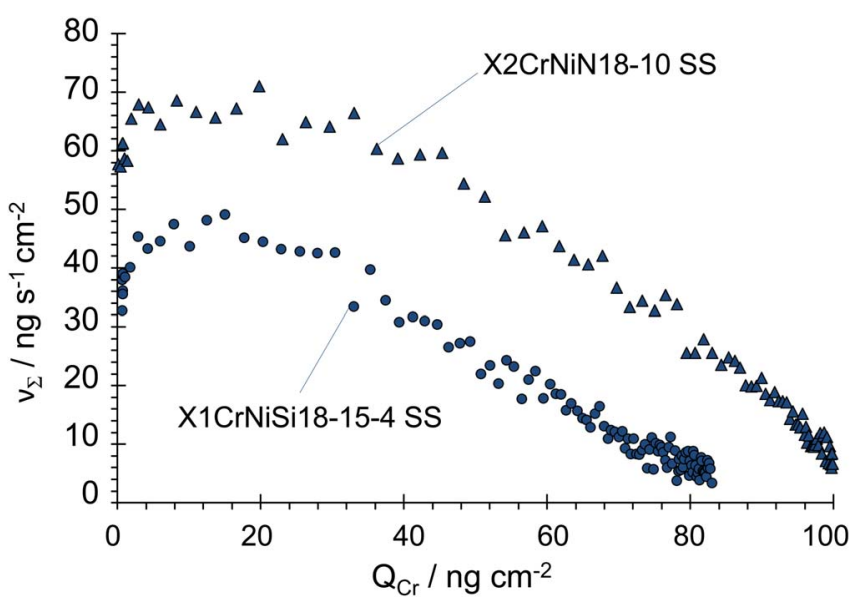

Figure 5. $v_{\Sigma}$ as a function of $\mathrm{Q}_{\mathrm{Cr}}$ for the $\mathrm{X} 1 \mathrm{CrNiSi} 18-15-4$ and the $\mathrm{X} 2 \mathrm{CrNiN18-10} \mathrm{SS}$ over a typical passivation period $(4) \rightarrow\left(1^{\prime}\right)$ in $2 \mathrm{~mol}$ $\mathrm{dm}^{-3} \mathrm{H}_{2} \mathrm{SO}_{4} \mathrm{~T}=25^{\circ} \mathrm{C}$.

In Fig. 5, $v_{\Sigma}$ is shown as a function of $\mathrm{Q}_{\mathrm{Cr}}$ for both materials in $\mathrm{H}_{2} \mathrm{SO}_{4}$. Note that the $\nu_{\mathrm{M}}$ values in Eq. 12 were corrected for the descending background of concentration as described in reference. ${ }^{28}$ It is seen that the early stages of passive film formation $\left(\mathrm{Q}_{\mathrm{Cr}}<5 \mathrm{ng}\right.$ $\mathrm{cm}^{-3}$ ) are associated with an increased dissolution rate which then remains stable until about $30 \mathrm{ng} \mathrm{cm}^{-2}$. This represents the increase in dissolution rate observed initially when the passivation potential is applied. Beyond this, the progressive passivation of the surface takes place and the dissolution rate drops off until $80 \mathrm{ng} \mathrm{cm}^{-2}$ for $3.5 \mathrm{wt} \%$ $\mathrm{Si}$ and $100 \mathrm{ng} \mathrm{cm}^{-2}$ for $0.3 \mathrm{wt} \% \mathrm{Si}$. Although Si contributes to the passive layer of the X1CrNiSi18-15-4 SS, Fig. 5 presents very similar slopes $\nu_{\Sigma}=f\left(Q_{\mathrm{Cr}}\right)$. Furthermore, the addition of $\mathrm{Si}$ in the composition of SS does not seem to affect the slope $\nu_{\Sigma}$ vs. $\mathrm{Q}_{\mathrm{Cr}}$ during passivation, however, it shifts the final value of $\mathrm{Q}_{\mathrm{Cr}}$ to $20 \mathrm{ng} \mathrm{cm}^{-2}$ as Si occupies the surface along with $\mathrm{Cr}$.

The kinetics of dissolution and passivation of X1CrNiSi18-15-4 $\mathrm{SS}$ in $\mathrm{HNO}_{3}$. - Active-passive cycles in $\mathrm{HNO}_{3}$ were attempted despite the difficulties inherent in this electrolyte. The SS was polarized in the active domain for two different values of potential $(-1.20 \mathrm{~V}$ vs. MSE in Fig. 6A and $-0.8 \mathrm{~V}$ vs. MSE in Fig 6B) for $600 \mathrm{~s}$ and then allowed to passivate spontaneously at the open circuit potential as shown in Fig. 6. At the active polarization potentials of -1.20 and $-0.8 \mathrm{~V}$ vs. MSE, all $\nu_{\mathrm{M}}$ increase similar to the situation for $\mathrm{H}_{2} \mathrm{SO}_{4}$ (Fig. 3), however the accelerated dissolution yields nearly a 10 -fold enhancement in the dissolution rates, even in the case of $-0.8 \mathrm{~V}$ vs. MSE. Elemental dissolution was congruent as indicated by the fact that $v^{\circ} \mathrm{Cr}=\nu_{\mathrm{Fe}}$ throughout the cycles. Right after releasing the potential and measuring its open circuit value, all $\nu_{M}$ decrease slowly toward the detection limit.

Unlike the situation in $\mathrm{H}_{2} \mathrm{SO}_{4}$, it is clear from Fig. 6 that within experimental error of about $1 \%, \nu^{\circ} \mathrm{Cr}=v_{\mathrm{Fe}}$ throughout the active-passive cycles. It is therefore not possible to extract reliable information on $\mathrm{Cr}$ enrichment on the surface during passivation or their excess dissolution during activation under the conditions investigated here. The $\nu^{\circ}{ }_{S i}$ differs in some places from $\nu_{\mathrm{Fe}}$ (indicated with $\mathrm{a} *$ in Fig. 6), however, these variations are in different points of the cycle in Figs. 6A and $6 \mathrm{~B}$, and they do not correlate with the onset of the potential steps, and therefore no further attempt was made to interpret them.

The results of Fig. 6 yield, for the first time, a kinetic measurement in real time for the spontaneous passivation of $\mathrm{SS}$ in $\mathrm{HNO}_{3}$. This is shown in Fig. 6 by the decrease of the elemental dissolution rates with time when the potential is released to open circuit after activating the alloy. As an aid to comparison between the two electrolytes, Fig. 7 gives the normalized rate, $\nu_{\Sigma} / \nu_{\Sigma \max }$, corrected for the decreasing background, as recorded during passivation of X1CrNiSi18-15-4 SS 
Table IV. Results obtained over active-passive cycles on X1CrNiSi18-15-4 $\mathrm{SS}$ in $2 \mathrm{~mol} \mathrm{dm}^{-3} \mathrm{H}_{2} \mathrm{SO}_{4}$ at $25^{\circ} \mathrm{C}$ depending on various times and values of activation and passivation each repeated between one and five times.

\begin{tabular}{|c|c|c|c|c|c|c|c|c|}
\hline \multicolumn{2}{|c|}{ Activation } & \multicolumn{2}{|c|}{ Passivation } & \multicolumn{3}{|c|}{$\Delta \mathrm{n} / \mathrm{nmol} \mathrm{cm}{ }^{-2}$} & \multicolumn{2}{|c|}{$\Delta \mathrm{Q}_{\mathrm{M}_{\max }}$} \\
\hline$\Delta \mathrm{t} / \mathrm{s}$ & E vs. MSE/V & $\Delta \mathrm{t} / \mathrm{s}$ & E vs. MSE/V & $\Delta \mathrm{n}_{\mathrm{e}_{\mathrm{ICP}}}$ & $\Delta \mathrm{n}_{\mathrm{e}_{\mathrm{ext}}}$ & $\Delta \mathrm{n}_{\mathrm{e}_{\mathrm{ext}}} / \Delta \mathrm{n}_{\mathrm{eICP}}$ & $\Delta \mathrm{Q}_{\mathrm{Cr}_{\max }} / \mathrm{ng} \mathrm{cm}^{-2}$ & $\Delta \mathrm{Q}_{\mathrm{Si}_{\max }} / \mathrm{ng} \mathrm{cm}^{-2}$ \\
\hline 100 & -2 & 100 & 0 & 53 & 56 & 1.06 & 130 & 50 \\
\hline 10 & -2 & 10 & 0 & 59 & 46 & 0.75 & 100 & 40 \\
\hline 10 & -2 & 10 & -0.20 & 50 & 52 & 1.03 & 100 & 40 \\
\hline 10 & -2 & 10 & 0.25 & 37 & 44 & 1.19 & 90 & 40 \\
\hline 10 & -1.8 & 10 & 0 & 57 & 63 & 0.81 & 130 & 50 \\
\hline 50 & -1.8 & 10 & 0 & 93 & 81 & 0.87 & 230 & 100 \\
\hline 90 & -1.8 & 10 & 0 & 71 & 52 & 0.73 & 200 & 80 \\
\hline 10 & -1.6 & 10 & 0 & 53 & 43 & 0.80 & 230 & 100 \\
\hline 10 & --1.2 & 10 & 0 & 44 & 40 & 0.90 & 150 & 50 \\
\hline 50 & -1.2 & 10 & 0 & 62 & 40 & 0.64 & 300 & 120 \\
\hline 90 & -1.2 & 10 & 0 & 66 & 58 & 0.88 & 290 & 150 \\
\hline & & & Mean & 60 & 52 & 0.89 & & \\
\hline & & & Standard deviation & 16 & 12 & 0.16 & & \\
\hline
\end{tabular}

in $\mathrm{H}_{2} \mathrm{SO}_{4}$ and $\mathrm{HNO}_{3}$. These curves reveal that the passivation kinetics of the X1CrNiSi18-15-4 SS are very similar in both electrolytes, which is consistent with the hypothesis of a very similar passive layer obtained at the end of passivation. This supports the idea that the results obtained in $\mathrm{H}_{2} \mathrm{SO}_{4}$ are transposable to $\mathrm{HNO}_{3}$.

Structure of the passive film on X1CrNiSi18-15-4 SS exposed to $\mathrm{HNO}_{3}$. - XPS measurements were performed on both SS after
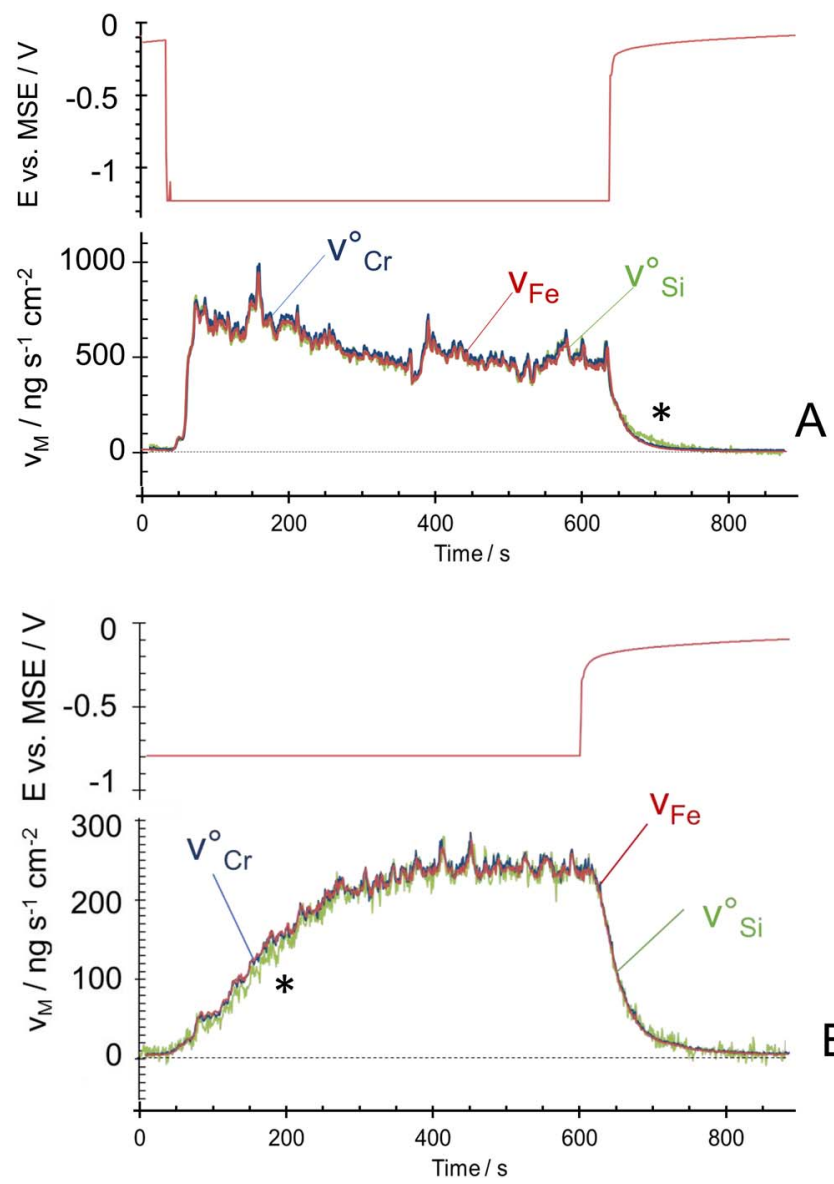

Figure 6. $v_{\mathrm{Fe}}, \mathrm{v}^{\circ} \mathrm{Cr}$ and $\mathrm{v}^{\circ} \mathrm{Si}$ vs. time for the $\mathrm{X} 1 \mathrm{CrNiSi} 18-15-4$ SS monitored over a typical active - passive cycle in $4 \mathrm{~mol} \mathrm{dm}^{-3} \mathrm{HNO}_{3} \mathrm{~T}=25^{\circ} \mathrm{C}$ (A) Activation potential of $-1.2 \mathrm{~V}$ vs. MSE. (B) Activation potential of -0.8 V vs. MSE. exposure to each electrolyte at $28^{\circ} \mathrm{C}$ and $100^{\circ} \mathrm{C}$, and in $\mathrm{HNO}_{3}$ for two different times of exposure (10 mins to 24 hours). As the results did not vary significantly between these conditions, typical spectra of $\mathrm{Cr}-2 p_{3 / 2}$ are shown in Fig. 8 and the quantitative average analyses are given in Table $\mathrm{V}$.

The results are consistent with the literature for passive films formed in similar environments. ${ }^{36,43}$ X1CrNiSi18-15-4 SS presents a high concentration of $\mathrm{Si}$ and $\mathrm{Cr}$ while X2CrNiN18-10 SS surface is mainly enriched in $\mathrm{Cr}$. Main differences in the chemical structure of the oxide layer concern $\mathrm{Cr}$ and $\mathrm{Si}$. The $\mathrm{Cr}-2 p_{3 / 2}$ core level spectra for $\mathrm{X} 2 \mathrm{CrNiN} 18-10 \mathrm{SS}$ oxide layer presents a complex multiplet structure (Fig. 8B) with the typical range of energies corresponding to chromic oxide $\mathrm{Cr}_{2} \mathrm{O}_{3} \cdot{ }^{45}$ But for the X1CrNiSi18-15-4 SS oxide layer (Fig. 8B), Si- $2 p$ core level energies were shifted to lower values from the $103.5-104.0 \mathrm{eV}$ range that is usually associated with $\mathrm{SiO}_{2}{ }^{46}$ For metal silicates, $\mathrm{Si}$ and associated metal elements core levels energies may shift as compared to pure metal oxides as it is the case of $\mathrm{Fe}$ silicate $^{47}$ or $\mathrm{Zr}$ silicate ${ }^{48}$ in comparison to $\mathrm{Fe}$ or $\mathrm{Zr}$ oxide. In the present case, $\mathrm{Cr}-2 p$ core levels energies seem to be shifted to higher values in the presence of $\mathrm{Si}$ in the oxide layer. Fig. 8 displays the comparison between the $\mathrm{Cr}-2 p_{3 / 2}$ photoelectron peaks for X1CrNiSi18-15-4 and X2CrNiN18-10 SS. A chemical shift of $0.4 \mathrm{eV}$ toward higher binding energy appears repetitively (over 8 experiments) for the oxide $\mathrm{Cr}$ contribution in the X1CrNiSi18-15-4 SS passive layer while the Cr metallic contribution is at the same binding energy for both SS. This result must be considered with great caution as the chemical shift is small. Nevertheless it is of the same order of magnitude as the shift found

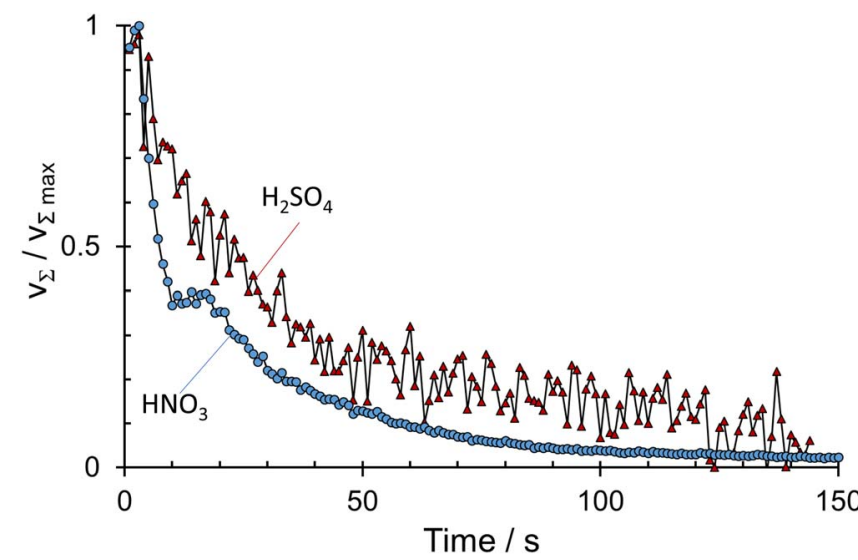

Figure 7. $v_{\Sigma} / v_{\Sigma \max }$ as a function of time for $\mathrm{X} 1 \mathrm{CrNiSi} 18-15-4$ SS during passivation in $\mathrm{H}_{2} \mathrm{SO}_{4}$ (red triangles) and $\mathrm{HNO}_{3}$ (blue circles) $\mathrm{T}=25^{\circ} \mathrm{C}$. The results have been corrected for the residence time distribution in the flow cell. 
Table V. Relative quantification by XPS measurements on passive layers after 10 mins and $24 \mathrm{~h}$ immersion in $\mathrm{H}_{2} \mathrm{SO}_{4}$ and $\mathrm{HNO}_{3}$ (averaged over 3 experiments for $\mathrm{H}_{2} \mathrm{SO}_{4}, 10$ experiments for $\mathrm{HNO}_{3}$ ).

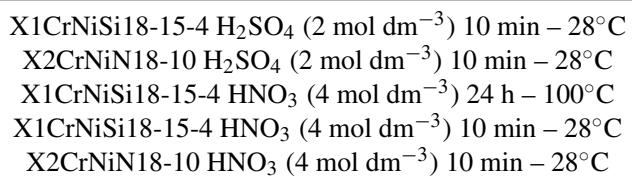

by Lee et $a l .{ }^{47}$ in the case of Fe silicates. The reproducibility of this result also supports the idea that $\mathrm{Cr}$ is actually involved in the silicate structure composing the oxide layer of the X1CrNiSi18-15-4 SS.

For the X1CrNiSi18-15-4 SS, XPS measurements reveal no drastic difference of chemical composition nor thickness between $\mathrm{H}_{2} \mathrm{SO}_{4}$ and $\mathrm{HNO}_{3}$. Even without measuring the passive layer thickness on TEM micrographs, it was possible to compare ratios of metallic and oxidized contributions of the elements in the XPS spectra between the two electrolytes. As they were all congruent between different conditions of passivation, it was possible to conclude that the thickness of the X1CrNiSi18-15-4 SS passive layer was not impacted by the nature of the electrolyte. From TEM micrographs (Fig. 9), it was shown that the X1CrNiSi18-15-4 SS passive layer is about 3 to $4 \mathrm{~nm}$ thick, amorphous and regular over the surface.

To determine the stoichiometry of these oxides, a first idea would be to determine a ratio $\frac{n_{C r}}{n_{S i}}$ from both XPS measurements and AESEC measurements. AESEC measurements lead to total amounts of $80 \pm$ $40 \mathrm{ng} \mathrm{cm}^{-2}$, of $\mathrm{Cr}$ and of $30 \pm 10 \mathrm{ng} \mathrm{cm}^{-2}$ of Si (from Fig. 4) to give $\mathrm{n}_{\mathrm{Cr}}=\mathrm{n}_{\mathrm{Si}}=\frac{n_{C r}}{n_{S i}}=1.4 \pm 0.2$. XPS gives $\frac{n_{C r}}{n_{S i}}=1.5 \pm 0.2$ (for 8 measurements). Firstly, it can be noticed that AESEC and XPS lead to a very similar ratio. An averaged result of X-EDS measurements performed over 7 profiles on FIB cross section of a passive layer formed on the $\mathrm{X} 1 \mathrm{CrNiSi} 18-15-4 \mathrm{SS}$ in $\mathrm{HNO}_{3}$ at $100^{\circ} \mathrm{C}$ for 24 hours is presented on Fig. 9 (colored areas representing standard deviation obtained over the measurements). Fig. 9 reveal a reproducible outer

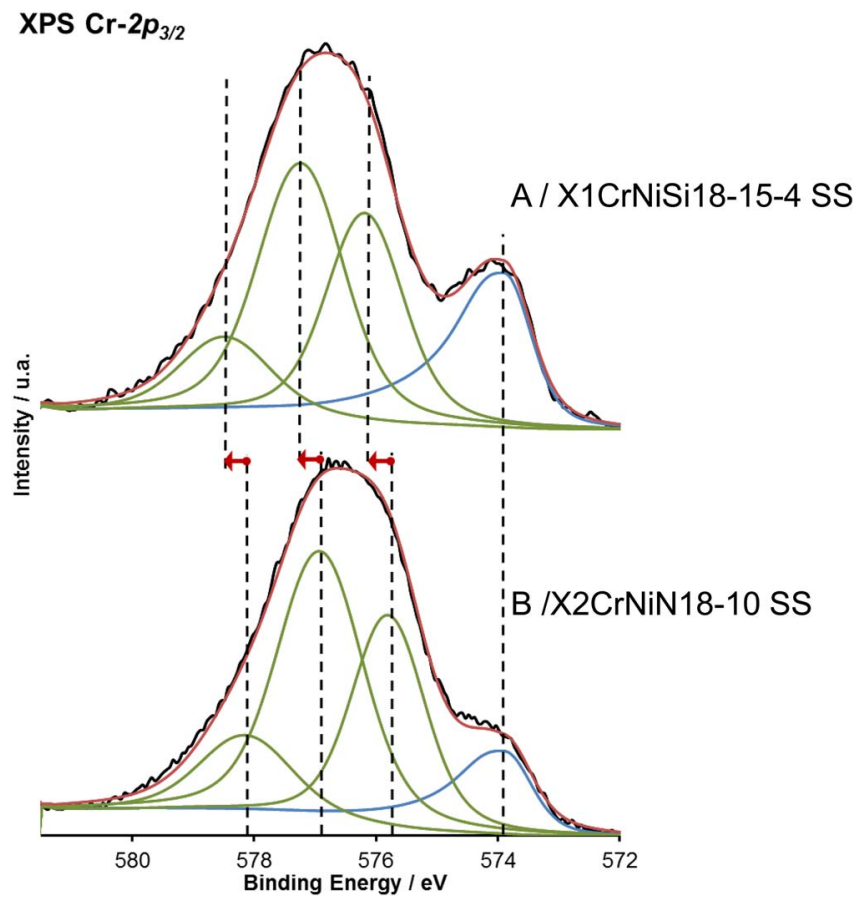

Figure 8. Cr-2 $\mathrm{p}_{3 / 2}$ XPS spectra of $\mathrm{X} 1 \mathrm{CrNiSi} 18-15-4$ and $\mathrm{X} 2 \mathrm{CrNiN} 18-10 \mathrm{SS}$ passive layers formed in $4 \mathrm{~mol} \mathrm{dm}^{-3} \mathrm{HNO}_{3}, \mathrm{~T}=25^{\circ} \mathrm{C}$ for 24 hours highlighting a typical example of chemical shift of the oxide $\mathrm{Cr}$ contribution on the X1CrNiSi18-15-4 SS.
$[\mathrm{Fe} O \mathrm{Ox}] /$ at. $\%$ $28 \pm 1$

$38 \pm 8$

$22 \pm 4$

$26 \pm 2$

$41 \pm 4$

$[\mathrm{Cr}$ Ox] $] /$ at. \%

[Si Ox]/at.\%

$43 \pm 2$

$62 \pm 8$

$51 \pm 5$

$48 \pm 1$

$59 \pm 5$

$30 \pm 1$

None

$27 \pm 6$

$26 \pm 3$

none

layer where Si prevails largely over Cr. X-EDS analysis revealed systematically the presence of $\mathrm{Si}$ at the extreme surface and a variation of the $\mathrm{Cr} / \mathrm{Si}$ ratio over the few nanometers thick oxide layer, from the surface to the oxide-metal interface.

Because of the resolution of the X-EDS $(0.5 \mathrm{~nm})$, it is impossible to precisely position the transition between two possible regions. Nevertheless, as the increases of $\mathrm{Cr}$ and $\mathrm{Si}$ in the first nanometers of the oxide layer are clearly not proportional, and the high reproducibility of this result (for a total of 7 measurements on two different samples), the results clearly indicate an extreme surface zone where the atomic ratio $\frac{n_{C r}}{n_{S i}}<1$ has been identified. This ratio was statistically measured at $0.7 \pm 0.1$.
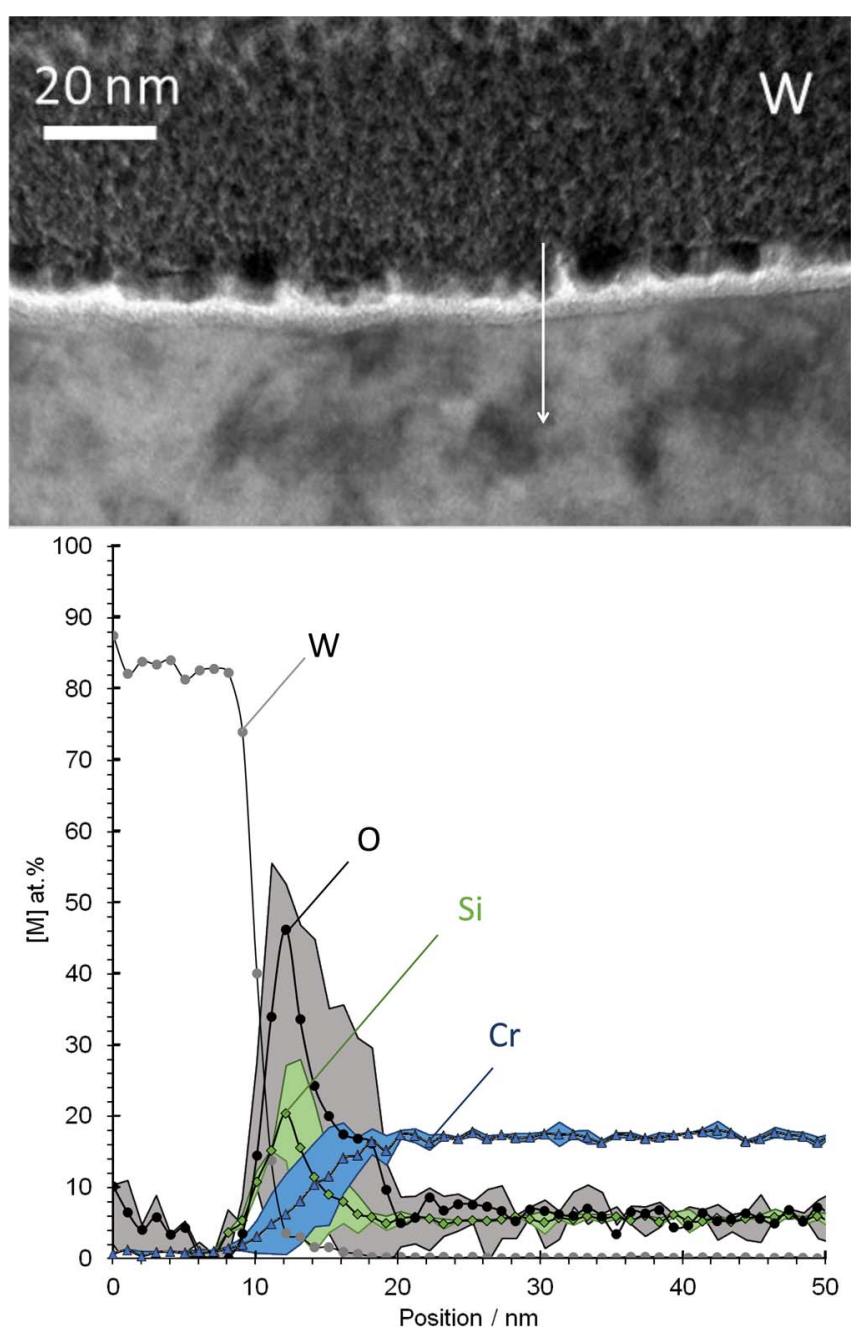

Figure 9. X-EDS line scan (TEM) of the passive layer of X1CrNiSi18-15-4 SS: (upper) TEM cross section showing the passive film; (lower) EDS elemental analysis across the passive film formed in $4 \mathrm{~mol} \mathrm{dm}^{-3} \mathrm{HNO}_{3} \mathrm{~T}=100^{\circ} \mathrm{C}$ for 24 hours. Two regions are observed where ratios $\mathrm{Cr} / \mathrm{Si}$ are $0.7 \pm 0.1$ and $2.1 \pm 0.3$. 
Based on these three techniques (AESEC, XPS, TEM-X-EDS), it is proposed that a minimum of two layers of different oxide ratios exist. After X-EDS measurements, a ratio for the inner layer was measured in the region between $\mathrm{n}_{\mathrm{Si}}>\mathrm{n}_{\mathrm{Cr}}$ and the region where the metal composition is reached and where $\frac{n_{C r}}{n_{S i}}=3.6 \pm 0.1$. In this inner layer, $\mathrm{Cr}$ appears as more concentrated and the atomic ratio calculated is $2.1 \pm 0.3$ which remains lower than the value calculated in the bulk metal.

Given all the precautions mentioned, the following considerations must be taken as hypothesis to be confirmed. Nevertheless, if the two oxide regions are of the same thickness, one would expect an averaged ratio of $1.4 \pm 0.2$ which would be consistent with AESEC and XPS to directly observe the two layers, supporting the hypothesis of a double layered oxide film for the X1CrNiSi18-15-4 SS. The outer layer would be composed of an oxide of a stoichiometry that could be $(\mathrm{Cr}: 2 ; \mathrm{Si}: 3)$. A chromic oxide type $\mathrm{Cr}_{2}\left(\mathrm{SiO}_{3}\right)_{3}$ is consistent with this stoichiometry, however this outer layer could also be hydrated. ${ }^{8}$ The inner oxide stoichiometry would rather correspond to $(\mathrm{Cr}: 2 ; \mathrm{Si}$ : 1) such as in $\mathrm{SiCr}_{2} \mathrm{O}_{5}$, for example

\section{Conclusions}

The direct observation by AESEC of $\mathrm{Fe}, \mathrm{Cr}$, and $\mathrm{Si}$ elemental dissolution during active - passive cycles is reported for two varieties of stainless steels in $4 \mathrm{~mol} \mathrm{dm}^{-3} \mathrm{HNO}_{3}$ and $2 \mathrm{~mol} \mathrm{dm}^{-3} \mathrm{H}_{2} \mathrm{SO}_{4}$. From a mass balance, it was possible to estimate the quantity of residual $\mathrm{Cr}$ and $\mathrm{Si}$ in the passive film for the case of $\mathrm{H}_{2} \mathrm{SO}_{4}$, and to follow its growth in real time during passivation as well as its dissolution during activation. It was shown in the present work that $\mathrm{Si}$ and $\mathrm{Cr}$ mainly contribute to the formation of the oxide layer of the X1CrNiSi18-15-4 $\mathrm{SS}$. From these measurements, it was possible to calculate enrichments of $\mathrm{Si}$ and $\mathrm{Cr}$ in the passive layer and the results were consistent with XPS ex situ measurements performed in $\mathrm{H}_{2} \mathrm{SO}_{4}$ and $\mathrm{HNO}_{3}$.

TEM coupled with X-EDS line scans gave passive film compositions that were consistent with XPS and AESEC measurements in terms of molar ratio $\frac{n_{C r}}{n_{S i}}$ averaged through the entire passive film. However they revealed an outer region where $\mathrm{Si}$ prevails over $\mathrm{Cr}$ suggesting the passive film consists of an outer and inner layer with $(\mathrm{Cr}$ : 2; $\mathrm{Si}: 3)$ and a $\mathrm{Cr}$ rich inner layer (Cr: $2 ; \mathrm{Si}: 1)$.

In $\mathrm{HNO}_{3}$, no selective dissolution was detectable. It is assumed that this selective behavior exists as the passive layers analyzed by XPS are very similar for both acids.

It is concluded that $\mathrm{Si}$ enrichment of an X2CrNiN18-10 type SS significantly modifies the chemistry of the passive layer. However, it still consists of a Cr-rich oxide with protective character for the material.

\section{Acknowledgments}

Authors are grateful to Areva, S.A. for financial support, Dr. Michel Tabarant for the GDOES analysis, and Dr. Michel Keddam for helpful discussions.

\section{References}

1. J. Keir, Philosophical Transactions of the Royal Society of London, 80, 359 (1790).

2. W. Hisinger and J. J. Berzelius, Gilberts Annalen, 27, 275 (1807).

3. Ch. F. Schönbein and M. Faraday, Philosophical Magazine, 9, 53 (1836).

4. M. Faraday, Experimental Researches in Electricity, 2, Dover, New York (1965).

5. C. L. McBee and J. Kruger, Electrochimica Acta, 17, 1337 (1972).

6. C. O. A. Olsson and D. Landolt, Electrochimica Acta, 48, 1093 (2003).
7. P. Fauvet, Nuclear corrosion science and engineering, 679, Woodhead Publishing, Cambridge (2012).

8. H-H. Strehblow, Electrochimica Acta, 212, 630 (2016).

9. D. D. Macdonald, Pure Applied Chemistry, 71, 951 (1999).

10. R. Kirchheim, B. Heine, S. Hofmann, and H. Hofsäss, Corrosion Science, 31, 573 (1990).

11. M. Legrand, B. Diawara, J. J. Legendre, and P. Marcus, Corrosion Science, 44, 773 (2002).

12. K. J. Vetter, Electrochemische Kinetik, Springer-Verlag, Berlin-GottingenHeidelberg, 748 (1961).

13. P. Schmuki, S. Virtanen, H. S. Isaacs, M. P. Ryan, A. J. Davenport, H. Böhm, and T. Stenberg, Journal of The Electrochemical Society, 145, 791 (1998).

14. F. Balbaud, European Journal of Inorganic chemistry, 665 (2000).

15. M. Ozawa, O. Yamamura, and K. Gonda, Journal of Nuclear Science and Technology, 22, 68 (2012).

16. B. Raj and U. K. Mudali, Progress in Nuclear Energy, 48, 283 (2006).

17. M. Pourbaix, Atlas of electrochemical equilibria in aqueous solutions, Pergamon Press, Oxford (1966)

18. A. Desestret, J. Ferriol, and G. Vallier, Materiaux et Techniques, 9, 621 (1977).

19. Y. Kuriki, M. Tamura, N. Yamanouchi, and K. Kiuchi, Third International Conference on Nuclear Fuel Reprocessing and Waste Management, xxii 1154, 1049 (1991).

20. O. V. Kasparova, Y. V. Baldokhin, and G. A. Kochetov, Protection of Metals, 38, 176 (2002).

21. G. Hochörtler and E. M. Horn, Metallic corrosion, II, 1447 (1981)

22. B. Ghiban, S. Ciuca, I. Carceanu, N. Ghiban, and I. Nedelcu, Metalurgia International, 13, 39 (2008).

23. L. Y. Gurvich and A. D. Zhirnov, Protection of metals, 31, 231 (1995).

24. T. Honda, T. Yokosuka, and Y. Arai, Corrosion 97, NACE (1997).

25. B. Laurent, N. Gruet, B. Gwinner, F. Miserque, M. Tabarant, and K. Ogle, Journal of the Electrochemical Society, 164(9), C481 (2017).

26. S. Haupt and H. H. Strehblow, Journal of Electroanalytical Chemistry, 228, 365 (1987).

27. V. Maurice and P. Marcus, Electrochimica Acta, 84, 129 (2012).

28. K. Ogle, M. Mokaddem, and P. Volovitch, Electrochimica Acta, 55, 913 (2010).

29. V. P. Razygraev, M. V. Lebedeva, S. A. Kabakchi, E. Y. B. Ponomareva, R. S., and L. P. Lobanova, Journal of Applied Chemistry USSR, 61 (1988).

30. D. G. Kolman, D. K. Ford, D. P. Butt, and T. O. Nelson, Corrosion Science, 39, 2067 (1997).

31. J. R. Myers, F. H. Beck, and M. G. Fontana, Corrosion, 9(21), 277 (1965)

32. K. Ogle and S. Weber, Journal of the Electrochemical Society, 147, 1770 (2000).

33. V. Shkirskiy, P. Keil, H. Hintze-Bruening, F. Leroux, P. Volovitch, and K. Ogle, Electrochimica Acta, 184, 203 (2015).

34. P. Lorbeer and W. J. Lorenz, Corrosion Science, 21, 79 (1981).

35. K. Ogle, J. Baeyens, J. Swiatowska, and P. Volovitch, Electrochimica Acta, 54, 5163 (2010).

36. F. Ruel, P. Volovitch, L. Peguet, A. Gaugain, and K. Ogle, Corrosion, 69, 536 (2013).

37. R. Robin, F. Miserque, and V. Spagnol, Journal of Nuclear Materials, 375, 65 (2008).

38. A. A. Hermas, K. Ogura, and T. Adachi, Electrochimica Acta, 40, 837 (1995).

39. J. S. Armijo and B. E. Wilde, Corrosion Science, 8, 649 (1968).

40. B. E. Wilde, Corrosion, 44, 699 (1988).

41. B. Ghiban and G. Cosmeleata, Innovation stainless steel, European stainless steel conference 183 (1993).

42. B. Ghiban and N. Ghiban, Scientific Bulletin Series B: Chemistry and Materials Science, 62, 79 (2000).

43. B. Baroux, Passivity of Metals and Semiconductors, Elsevier, Bombannes, France (1983) 531.

44. E. Tcharkhtchi-Gillard, M. Benoit, P. Clavier, B. Gwinner, F. Miserque, and V. Vivier, Corrosion Science, 107, 182 (2016).

45. L. Marchetti, F. Miserque, S. Perrin, and M. Pijolat, Surface and Interface Analysis, 47, 632 (2015).

46. H. S. Nalwa, Handbook of Surfaces and Interfaces of Materials, (2001).

47. Y. Lee, A. J. Bevolo, and D. W. Lynch, Surface Science, 188, 267 (1987).

48. M. J. Guittet, J. P. Crocombette, and M. Gautier-Soyer, Physical Review B, 63, 125117 (2001).

49. V. Maurice, W. P. Yang, and P. Marcus, Journal of the Electrochemical Society, 143(3), 1182 (1996).

50. N. B. Hakiki, S. Boudin, B. Rondot, and M. Da Cunha Belo, Corrosion Science, 37(11), 1809 (1995).

51. W. P. Yang, D. Costa, and P. Marcus, Journal of the Electrochemical Society, 141(1), 111 (1994).

52. P. Marcus and J. M. Grimal, Corrosion Science, 33, 805 (1992).

53. V. Maurice, W. P. Yang, and P. Marcus, Journal of the Electrochemical Society, 145, 909 (1998).

54. R. Kirchheim, in Modification of Passive films, (P. Marcus, B. Baroux, and M. Keddam, eds.), Institute of Materials, London (1994). 